\title{
ANTIHYPERURICEMIC AND XANTHINE OXIDASE INHIBITORY ACTIVITIES OF FRACTIONS FROM ETHANOLIC LEAVES EXTRACT OF STELECHOCARPUS BURAHOL
}

\author{
TITIK SUNARNI ${ }^{1,2 *}$, FRANSISKA LEVIANA ${ }^{2}$, IRDA FIDRIANNY ${ }^{1}$, MARIA IMMACULATA ${ }^{3}$, \\ KOMAR RUSLAN WIRASUTISNA ${ }^{1}$
}

${ }^{1}$ Pharmaceutical Biology Reseacrh Group, School of Pharmacy, Bandung Institute of Technology, Indonesia. ${ }^{2}$ Department of Pharmaceutical Biology, Faculty of Pharmacy, Setia Budi University, Indonesia. ${ }^{3}$ Pharmacology-Clinical Pharmacy Research Group, School of Pharmacy, Bandung Institute of Technology, Indonesia. Email: titiksunarni@yahoo.co.id

Received: 26 July 2016, Revised and Accepted: 11 August 2016

\section{ABSTRACT}

Objective: The aims of the research were to evaluate antihyperuricemic and xanthine oxidase (XO) inhibitory activity of fractions from ethanolic leaves extract of Stelechocarpus burahol.

Methods: S. burahol leaves powder was extracted in ethanol by maceration method, then extract was fractionated by liquid-liquid extraction method using n-hexane and ethyl acetate. Hyperuricemic rat model was induced by administered potassium oxonate intraperitoneally. The activity of these fractions on XO inhibitory was determined by measuring the uric acid (UA) formation using ultraviolet-visible spectrophotometry method after incubating with XO.

Results: The n-hexane and ethyl acetate fractions significantly ( $\mathrm{p}<0.05)$ reduce the uric level by $32.0 \%$ and $28.0 \%$ respectively compared to UA level of hyperuricemic group at $1 \mathrm{hr}$ after drug administration $(\mathrm{p}<0.05)$. On XO inhibitory activity test, only n-hexane fraction exhibited poor XO inhibitory activity.

Conclusion: The n-hexane and ethyl acetate fractions from ethanolic leaves extract of $S$. burahol had antihiperuricemic activity, but less inhibitor effect on XO activity.

Keywords: Stelechocarpus burahol, Liquid-liquid extraction, Antihyperuricemic, Xanthine oxidase inhibitory activity.

(C) 2016 The Authors. Published by Innovare Academic Sciences Pvt Ltd. This is an open access article under the CC BY license (http://creativecommons org/licenses/by/4. 0/) DOI: http://dx.doi.org/10.22159/ajpcr.2016.v9i6.14314

\section{INTRODUCTION}

Stelechocarpus burahol (Bl.) Hook F. and Th, which is known as Kepel, belonging to the family Annonaceae, widely distributed in Indonesia, especially in Central Java. Traditionally, in Indonesia, especially Java, the leaf of this plant is used to treat gout. The ethanolic extract of $S$. burahol leaves had been reported to have antihyperuricemic activity and its phytochemical screening revealed that $S$. burahol contained terpenoid, flavonoid, alkaloids, and tannins compounds [1,2]. Many Indonesian plants have been used to prevent and to treat gout; however, it has the lack of sufficient scientific evidence. The previous study showed that the ethanolic extract of this plant gave antihyperuricemic activity [2]. The objectives of the present study are to determine in vivo antihyperuricemic effect and in vitro xanthine oxidase (XO) inhibitory activity of fractions from ethanolic leaves extract of $S$. burahol.

Uric acid (UA) is a weak acid, with an ionization constant of acid (pKa) 5.75-10.3. At the physiological $\mathrm{pH}$ of the extracellular compartment (pH 7.4), 99\% of UA is in the ionized form as urate (as monosodium urate in blood and as potassium, ammonium, and calcium urate in urine) [3]. UA is the final product of purine nucleotide catabolism. Purine nucleotides are derived from both endogenous and exogenous sources. Gout is a poorly soluble substance, usually associated with hyperuricemia, high serum UA levels [4]. Hyperuricemia is largely classified into 3 types: The over production-type, in which the production of UA, such as the biosynthesis or decomposition/ catabolism of purine, is increased; decreased excretion-type, in which the excretion of UA from the kidneys is low, and mixed-type, in which both the mentioned types above are observed [5]. Chronic hyperuricemia may cause UA precipitation in joints and tissues leading to complication such as gout, nephrolithiasis, and chronic nephropathy. UA deposit may be asymptomatic [6,7]. XO inhibitors are agents that directly inhibit the synthesis of UA in vivo and thus these drugs should be given as the first choice in the therapeutic approach for the treatment of gout and hyperuricemia. XO converts hypoxanthine to xanthine and xanthine to UA in our body [8]. Certain active constituents present in crude plant extracts like flavonoids and polyphenolic compounds have been reported to posses XO inhibitory [9].

\section{METHODS}

\section{Materials}

Xanthine, XO, potassium dihydrogen phosphate, dimethyl sulfoxide (DMSO), potassium oxonate were purchased from Sigma Chemicals Co. Allopurinol was obtained from Ifars Pharmaceutical Laboratories. The UA kit was purchased from sclavo diagnostic.

Preparation of sample

The plant materials were collected from Central Java, Indonesia, and determined in School of Life Science and Technology, Bandung Institute of Technology. The materials were washed, sorted while wet, dried, and grinded into powder.

\section{Extraction and fractionation}

The 500 g dried leaves powder of $S$. burahol was extracted by maceration using $2.5 \mathrm{l}$ ethanol $96 \%$ for 5 days at room temperature. After 5 days, the mixture was filtered and the residue was washed with using ethanol and treated for 5 days as the same as treatment before. Extract was evaporated by rotary evaporator yielding ethanol extract of $S$. burahol $51.1 \mathrm{~g}$. The $30 \mathrm{~g}$ of ethanolic extract was added with aquadest, then fractionated by liquid-liquid extraction successively with equal volume of n-hexane and ethyl acetate. Each fraction was then concentrated using rotary evaporator under reduced pressure to obtain n-hexane fraction $20 \%$, ethyl acetate fraction $12 \%$, aqueous fraction $32 \%$. 
Animal

Male Wistar rats weighed 170-200 g (age 7-8 weeks) were obtained from the animal laboratory of School of Pharmacy, Bandung Institute of Technology. The rats were allowed to adapt to their environment at constant temperature of $25^{\circ} \mathrm{C}$ for a week before being used. They were given free access to feed standard pellets and water during the study. All of procedures were approved by Animal Ethics Committee, Bandung Institute of Technology, with a certificate no 09/KEPHP-ITB/03-2015.

\section{Animal model of hyperuricemia in rats and drug administration}

Hyperuricemic rat model was prepared by giving potassium oxonate as uricase inhibitor. The experiment was performed according to the Liu's method [10] with minor modification in potassium oxonate dose. Rats were divided randomly into normal control, hyperuricemic control, standard (allopurinol), and sample groups ( $\mathrm{n}=6 \mathrm{each})$. Allopurinol and fractions of $S$. burahol were prepared in suspension dosage form using $0.3 \%$ carboxymethylcellulose sodium (CMC-Na). The dose of fraction was calculated from percentage of yielding fraction. The n-hexane fraction at dose of $30 \mathrm{mg} / \mathrm{kg}$ body weight (bw), ethyl acetate fraction $20 \mathrm{mg} / \mathrm{kg}$ bw, and aqueous fraction $50 \mathrm{mg} / \mathrm{kg}$ bw were given orally to rats. As a standard, allopurinol was administered in the same manner at a dose of $10 \mathrm{mg} / \mathrm{kg} \mathrm{bw}$. The volume of the suspension which was administered based on bw of rat. The rats were fasted 1 day before being used in the experiment. Water was withdrawn from the animals $1 \mathrm{hr}$ prior to drug administration. The animals were transferred to the laboratory at least $1 \mathrm{hr}$ before the potassium oxonate-induced hyperuricemia experiment. Before potassium oxonate administration, blood was collected for determining serum UA level on $0 \mathrm{~h}$. Briefly, rats were injected intraperitoneally with potassium oxonate $(250 \mathrm{mg} / \mathrm{kg}$ bw suspended in CMC-Na 0.3\%) to increase the serum UA level, except normal control group, $1 \mathrm{hr}$ before the drug administration. Blood samples were collected from rats by tail vein bleeding in duration $1-3^{\text {rd }} \mathrm{h}$ for obtaining UA level on $1^{\text {st }}, 2^{\text {nd }}$, and $3^{\text {rd }} \mathrm{h}$ after drug administration. The blood was allowed to clot for 30 minutes at room temperature and then centrifuged at $10.000 \times \mathrm{g}$ for 7 minutes to obtain the serum. The serum was stored at $-20^{\circ} \mathrm{C}$ before UA level determination. Serum UA level was determined by enzymatic-colorimetric method, using a standard diagnostic kit, according to manufacturer's instructions.

\section{In vitro XO inhibitory activity}

Experiment was conducted according to methods which were reported by Umamaheswari et al. [11] and Abdullahi et al. [12] with minor modification in phosphate buffer volume. The mixture which consisted of $1 \mathrm{ml}$ fraction $(25-200 \mu \mathrm{g} / \mathrm{ml}), 0.9 \mathrm{ml}$ phosphate buffer $50 \mathrm{mM}\left(\mathrm{pH} 7.5\right.$ at $\left.25^{\circ} \mathrm{C}\right)$, and $0.1 \mathrm{ml} \mathrm{XO}$ enzyme solution $(0.1 \mathrm{unit} / \mathrm{ml}$ in phosphate buffer, $\mathrm{pH}$ 7.5) was prepared immediately before using. After pre-incubation at $25^{\circ} \mathrm{C}$ for 15 minutes, the reaction was initiated by adding $2 \mathrm{ml}$ of substrate solution $(0.15 \mathrm{mM}$ xanthine solution, prepared fresh). Then, the mixture was incubated at $25^{\circ} \mathrm{C}$ for 30 minutes. The reaction was then stopped by adding $1 \mathrm{ml} 1 \mathrm{~N}$ hydrochloric acid, and the absorbance was measured at $\lambda 287 \mathrm{~nm}$ using ultraviolet-visible (UV-VIS) spectrophotometer. Different concentrations of the fraction $(25-200 \mu \mathrm{g} / \mathrm{ml})$ were dissolved in DMSO. The fractions were added in appropriate volume, so that the final concentration of DMSO in the assay did not exceed $5 \%$ of the total volume. Allopurinol $(0.2-2.0 \mu \mathrm{g} / \mathrm{ml}$, a known inhibitor of $\mathrm{XO}$, was used as the positive control. All of the experiments were conducted in triplicate. The XO inhibitory activity of fraction was assessed as the inhibitory percentage (\%):

Inhibition $(\%)=\left\{\frac{(A-B)-(C-D)}{(A-B)}\right\} \times 100$

Where A is the activity of the enzyme without the fraction, B is the control of $\mathrm{A}$ without the fraction and enzyme; $\mathrm{C}$ and $\mathrm{D}$ are the activities of the fraction with and without XO, respectively. The assay was done in triplicate and inhibitory concentration $\left(\mathrm{IC}_{50}\right)$ values were calculated from the percentage of inhibition.

\section{Statistical analysis}

Results showed the mean \pm standard deviation. The significant difference was statistically calculated by the analysis of variance (one way) followed by Tukey post hoc test. Statistical significant was set at $\mathrm{p}<0.1,0.05$, and 0.01 .

\section{RESULTS AND DISCUSSION}

The antihyperuricemic activities of n-hexane, ethyl acetate, and aqueous fractions of $S$. burahol extract on hyperuricemic rats using potassium oxonate were shown in Table 1 and Fig. 1. Potassium oxonate is uricase inhibitor which can induce hyperuricemia condition in rats. The rat which is induced by potassium oxonate can serve as a useful hyperuricemia animal model to evaluate sample that affect serum UA levels and also to evaluate possible therapeutic agents in certain disorders associated with abnormal UA levels. Treatment with potassium oxonate cause hyperuricemia in rats, as indicated with the drastic increasing in UA levels compare to normal rats.

UA level in all of treatment groups before potassium oxonate treatment at $0 \mathrm{~h}$ was not different from each other as well as with normal control rats. Each animal in normal control group which was received vehicle only (CMC-Na) showed no different in serum UA level. The orally pre-treatment using allopurinol as standard at a dose of $10 \mathrm{mg} / \mathrm{kg}$ bw elicited significantly reduction in UA level in hyperuricemia rat at $1-3^{\text {rd }} \mathrm{hr}$ after treatment $(\mathrm{p}<0.05)$. The UA level of allopurinol group $1-3^{\text {rd }}$

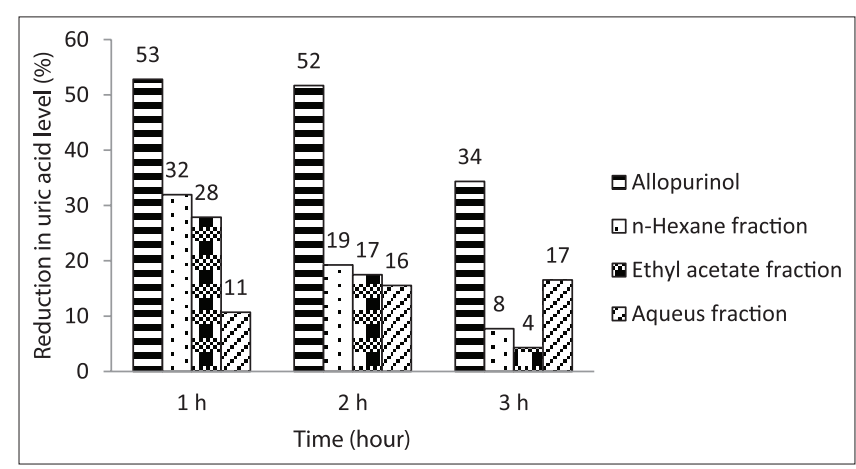

Fig. 1: Reduction in serum uric acid level after fraction treatment in hyperuricemia rat

Table 1: Serum uric acid level of hyperuricemia rat before and after giving fractions of $S$. burahol

\begin{tabular}{|c|c|c|c|c|}
\hline \multirow[t]{2}{*}{ Group } & \multicolumn{4}{|c|}{ Serum uric acid level (mg/dl) } \\
\hline & $\mathbf{0 ~ h}$ & $1 \mathrm{~h}$ & $2 \mathrm{~h}$ & $3 \mathbf{h}$ \\
\hline Normal control & $2.63 \pm 0.33$ & $2.42 \pm 0.37^{\mathrm{ry}}$ & $2.34 \pm 0.28^{r}$ & $2.46 \pm 0.39^{r}$ \\
\hline Hyperuricemic control & $2.54 \pm 0.26$ & $3.86 \pm 0.25^{\mathrm{cz}}$ & $4.00 \pm 0.39^{c z}$ & $3.35 \pm 0.25^{\mathrm{cz}}$ \\
\hline Allopurinol & $2.46 \pm 0.36$ & $1.82 \pm 0.40^{\mathrm{br}}$ & $1.93 \pm 0.16^{\mathrm{r}}$ & $2.20 \pm 0.51^{\mathrm{r}}$ \\
\hline $\mathrm{N}$-hexane fraction & $2.52 \pm 0.20$ & $2.63 \pm 0.16^{\mathrm{rz}}$ & $3.23 \pm 0.23^{\mathrm{crz}}$ & $3.09 \pm 0.65^{z}$ \\
\hline Ethyl acetate fraction & $2.74 \pm 0.36$ & $2.78 \pm 0.19^{\mathrm{rz}}$ & $3.30 \pm 0.28^{\mathrm{crz}}$ & $3.21 \pm 0.28^{\mathrm{az}}$ \\
\hline Aqueous fraction & $2.36 \pm 0.40$ & $3.47 \pm 0.26^{\mathrm{cz}}$ & $3.38 \pm 0.37^{\mathrm{cqz}}$ & $2.80 \pm 0.56$ \\
\hline
\end{tabular}

a,b,c: Compared to normal control ( $p<0.1,0.05,0.01), p, q, r$ : Compared to hyperuricemic control $(p<0.1,0.05,0.01)$, x,y,z: Compared to allopurinol group ( $p<0.1,0.05,0.01$ ), n-hexane fraction: $30 \mathrm{mg} / \mathrm{kg}$ bw, ethyl acetate fraction: $20 \mathrm{mg} / \mathrm{kg} \mathrm{bw}$, aqueous fraction: $50 \mathrm{mg} / \mathrm{kg}$ bw, allopurinol $10 \mathrm{mg} / \mathrm{kg}$ bw 
Table 2: In vitro xanthine oxidase inhibitory activity of fractions of $S$. burahol

\begin{tabular}{|c|c|c|c|c|c|}
\hline \multirow{2}{*}{$\begin{array}{l}\text { Materials } \\
\text { fraction }\end{array}$} & \multicolumn{4}{|c|}{ Percentage of xanthine oxidase inhibition } & \multirow[t]{2}{*}{$\mathrm{IC}_{50}(\mu \mathrm{g} / \mathrm{ml})$} \\
\hline & $25 \mu \mathrm{g} / \mathrm{ml}$ & $50 \mu \mathrm{g} / \mathrm{ml}$ & $100 \mu \mathrm{g} / \mathrm{ml}$ & $200 \mu \mathrm{g} / \mathrm{ml}$ & \\
\hline N-hexane & $-0.24 \pm 0.97$ & $2.48 \pm 2.80$ & $8.22 \pm 4.30$ & $16.55 \pm 3.88$ & $>200$ \\
\hline Ethyl acetate & $-3.38 \pm 6.22$ & $-5.48 \pm 25.74$ & $-13.01 \pm 16.85$ & $-27.03 \pm 39.04$ & - \\
\hline Aquoeus & $3.71 \pm 5.74$ & $0.33 \pm 2.34$ & $-0.64 \pm 3.15$ & $0.61 \pm 3.88$ & - \\
\hline Standard & \multicolumn{4}{|c|}{ Percentage of xanthine oxidase inhibition } & $\mathrm{IC}_{50}(\mu \mathrm{g} / \mathrm{ml})$ \\
\hline Allopurinol & $1.17 \pm 1.72$ & $1.71 \pm 1.40$ & $14.75 \pm 5.53$ & $62.94 \pm 3.71$ & $1.76 \pm 0.11$ \\
\hline
\end{tabular}

-: Not identified, no decreasing in absorbance, $\mathrm{IC}_{50}$ : Inhibitory concentration

$\mathrm{h}$ after orally treatment was not different compared to normal control group. This data indicated that treatment with allopurinol had completely recovery and could reduce serum UA level until normal condition. The profile UA level at $3^{\text {rd }}$ hrs after sample administration still increased in hyperuricemic group, whereas the serum UA level in fraction group at $1^{\text {st }} \mathrm{hr}$ and $2^{\text {nd }} \mathrm{hrs}$ were significantly different compared to hyperuricemic group $(\mathrm{p}<0.05)$ and only at $1^{\text {st }} \mathrm{hr}$ showed no different with normal control. These data indicated that the n-hexane and ethyl acetate fractions had potential antihyperuricemic activity, however need longer time to return to normal condition.

Clinically allopurinol is used as urate-lowering agent, relatively low cost, and generally acceptable safety profile. Allopurinol is a structural analog of hypoxanthine, while its active metabolite oxypurinol is a structural analog of xanthine. Allopurinol and its metabolite oxypurinol are both substrates and inhibitors of $\mathrm{XO}$, blocking the conversion of hypoxanthine to xanthine to UA [13]. Adverse reactions from allopurinol are generally uncommon and most are mild. The most frequent toxicities are rash, gastrointestinal intolerance such as diarrhea, headache, and leucopenia. Although in general very rare, allopurinol exposure is one of the most common causes of toxic epidermal necrolysis and StevensJohnson syndrome [14].

$1 \mathrm{hr}$ after oral treatment of n-hexane fraction $30 \mathrm{mg} / \mathrm{kg}$ bw, ethyl acetate fraction $20 \mathrm{mg} / \mathrm{kg}$ bw demonstrated significantly different $(\mathrm{p}<0.05)$ in reducing of UA level by 32.0 and $28.0 \%$, respectively (Fig. 1). Serum UA level of n-hexane fraction group was no significant difference compared to ethyl acetate fraction group. This means that the two fractions have the same potency in lowering UA level. In contrast, the aqueous fraction at a dose of $50 \mathrm{mg} / \mathrm{kg}$ bw showed no activity in lowering UA level. The antihyperuricemic activity of $\mathrm{n}$-hexane and ethyl acetate fractions were also seen at $2^{\text {nd }}$ hrs, whereas at the aqueous fraction start to reduce the UA level. Those data indicated that $n$-hexane and ethyl acetate fractions had stronger antihyperuricemic activity and could start to reduce UA level than aqueous fraction. $\mathrm{N}$-hexane and ethyl acetate fractions were supposed to contain nonpolar and semipolar components, which more active compared to polar substances in aqueous fraction. Phytochemical screening of extract showed the presences of flavonoid, tannin, and alkaloid [2]. Flavonoids are group of polyphenolic compounds which have been proved to possess XO inhibitory activity. Oral administration of quercetin, morin, myricetin, kaempherol, apigenin, and puerarin, which were soluble in ethyl acetate, had ability to reduce serum UA level in hyperuricemic mice induced by potassium oxonate [15]. Other polyphenol, lignin compounds: Phyllanthin and hypophylanthin as the bioactive constituent were reported to give significantly reduced the plasma UA level [16].

$\mathrm{XO}$ is the enzyme that catalyzes the metabolism of hypoxanthine to xanthine and then xanthine to UA. XO use oxygen to yield superoxide anion and hydrogen peroxide which contribute to oxidative damage of living tissues [17]. XO inhibitor is the most important of anti gout agent.

The three fractions of ethanolic leaves extract of $S$. burahol were assessed for their in vitro XO inhibitory activities. The XO inhibitory activity was evaluated by UV-VIS spectrophotometry under aerobic conditions using xanthine as the substrate. The presence of XO inhibitory activity can be determined through the decreasing in production of UA, which can be seen in its absorbance by UV-Vis spectrophotometry. Allopurinol as standard showed very strong inhibitory activity with $\mathrm{IC}_{50} 1.76 \mu \mathrm{g} / \mathrm{ml}$ (Table 2). Those fractions of S. burahol showed no effect on XO inhibitory activity. $\mathrm{N}$-hexane fraction gave inhibitory activity with $\mathrm{IC}_{50}$ more than $200 \mu \mathrm{g} / \mathrm{ml}$, which was categorized non active. Like the results shown in this study, Sunarni et al. [2] and Purwantiningsih et al. [18] also found lower inhibitory activity but had significant activity antihiperuricemic in vivo of ethanolic extract. Huang et al. [19] reported that the tested flavonoids did not show a significant effect on XO inhibitory activity in vitro, but have significant effect on $\mathrm{XO}$ inhibitory activities in vivo in hyperuricemia mice. This study revealed that the n-hexane and ethyl acetate fractions of $S$. burahol have no effect on XO inhibitory activity, however have significant effect in lowering serum UA level in hyperuricemia rats (in vivo model). The inconsistencies results between in vitro and in vivo may be due to the pharmacodynamic activity of those fractions. These research results also revealed that in vitro result is not always in line with in vitro. It not means the substances showed no effect on in vitro test, will have no activity in vivo also.

\section{CONCLUSION}

The n-hexane and ethyl acetate fractions of $S$. burahol showed no effect on XO inhibitory activity in vitro however had significant effect in lowering serum UA level in hyperuricemic rats in vivo.

\section{ACKNOWLEDGMENT}

We gratefully acknowledge to the Ministry of Research, Technology and Higher Education, Government of Indonesia, for research grant in fundamental research program.

\section{REFERENCES}

1. Purwantiningsih, Purwantini I, Santosa D. Identification of standard parameters of kepel leaves [Stelechocarpus burahol (B1.) Hook. F. \& Th.] And the extract as raw material for antihyperuricemic medicaments. Asian J Pharm Clin Res 2011;4(1):149-53.

2. Sunarni T, Leviana F, Fidrianny I, Iwo MI, Wirasutisna KR Antihyperuricemic activity of four plants Annonaceae using hyperuricemic rats model and enzyme assay. Asian J Pharm Clin Res 2015;8(6):250-3

3. Grassi D, Ferri L, Desideri G, Giosia PD, Cheli P, Pinto RD, et al. Chronic hyperuricemia, uric acid deposit and cardiovascular risk. Curr Pharm Des 2013;19(13):2432-8.

4. Katzung BG, Masters SB, Trevor AJ. Basic and Clinical Pharmacology. $11^{\text {th }}$ ed. New York: McGraw Hill Companies; 2009. p. 638-42.

5. Hokazono H, Omori T, Ono K. Anti-hyperuricemic effect of fermented barley extract is associated with increased urinary uric acid excretion. Food Sci Technol Res 2010;6(4):295-304.

6. Dincer HE, Dincer AP, Levinson DJ. Asymptomatic hyperuricemia: To treat or not to treat. Cleve Clin J Med 2002;69(8):594-608.

7. Kim KY, Schumacher HR, Hunsche E, Wertheimer AI, Kong SX. A literature review of the epidemiology and treatment of acute gout. Clin Ther 2003;25(6):1593-617. 
8. Kuo CY, Kao ES, Chan KC, Lee HJ, Huang TF, Wang CJ. Hibiscus sabdariffa L. Extracts reduce serum uric acid levels in oxonate-induced rats. J Funct Food 2012;4(1):375-81.

9. Sreejith M, Kannappan N, Santhiagu A, Marathakam A, Ajith PM, Jasemine S. In vitro xanthine oxidase inhibitory and antioxidant activities of aerial parts of Flacourtia sepiaria Roxb. Orient Pharm Exp Med 2013;13:113-20.

10. Liu X, Chen R, Shang Y, Jiao B, Huang C. Lithospermic acid as a nove xanthine oxidase inhibitor has anti-inflammatory and hypouricemic effects in rats. Chem Biol Interact 2008;176(2-3):137-42.

11. Umamaheswari M, Asokkumar K, Sivashanmugam AT, Remyaraju A Subhadradevi V, Ravi TK. In vitro xanthine oxidase inhibitory activity of the fractions of Erythina stricta Roxb. J Ethnopharmacol 2009;124(3):646-8.

12. Abdullahi A, Hamzah RU, Jigam AA, Yahya A, Kabiru AY, Muhammad $\mathrm{H}$, et al. Inhibitory activity of xanthine oxidase by fractions Crateva adansonii. J Acute Dis 2012;1(2):126-9.

13. McGill NW. Review: The epidemiology and treatment of gout. Rheumatol Res Rev 2011;3:73-82.
14. Gaffo AL, Saag KG. Febuxostat: The evidence for its use in the treatment of hyperuricemia and gout. Core Evid 2009;4:25-36.

15. Mo SF, Zhou F, Yao-Zhong LV, Hu QH, Zhang DM, Kong LD. Hypouricemic action of selected flavonoids in mice: Structure-activity relationships. Biol Pharm Bull 2007;30(8):1551-6.

16. Murugaiyah V, Chan KL. Mechanisms of antihyperuricemic effect of Phyllanthus niruri and its lignin constituents. J Ethnopharmaco 2009;124(2):233-9.

17. Alsultanee IR, Ewadh MJ, Mohammed MF. Novel natural anti gout medication extract from Momordica charantia. J Nat Sci Res 2014;4(7):16-24

18. Purwantiningsih, Hakim AR, Purwantini I. Antihyperuricemic activity of the kepel (Stelechocarpus burahol (B1.) Hook. F. \& Th.) Leaves extract and xanthine oxidase inhibitory study. Int J Pharm Pharm Sci 2010;2(2):122-7.

19. Huang J, Wang S, Zhu M, Chen J, Zhu X. Effects of genistein, apigenin quercetin, rutin and astilbin on serum uric acid levels and xanthine oxidase activities in normal and hyperuricemic mice. J Food Chem Toxicol 2011;49(9):1943-7. 